\title{
PENERAPAN SISTEM DAN PROSEDUR UANG PERSEDIAAN PADA BADAN PERENCANAAN PENELITIAN DAN PENGEMBANGAN KABUPATEN MINAHASA SELATAN
}

\author{
Magfirah S. Rahayu ${ }^{1}$, Hendrik Manossoh ${ }^{2}$ Stanley Kho Waladouw ${ }^{3}$ \\ 1,2,3 Jurusan Akuntansi, Fakultas Ekonomi dan Bisnis, Universitas Sam Ratulangi, Jl. Kampus Bahu, Manado, \\ 95115, Indonesia \\ E-mail : magfirahrahayuu@yahoo.com
}

\begin{abstract}
Public estimate is a planning tool as well as local financial control, the execution of expenditure by local government to do an activity must be accounted by PPTK (Activity Technical Management Officer) on a timely basis. Fundamentally, Money Inventory (MI) can only be provided to finance the operational payment needs of the work unit, in the process of absorption of APBD, fund cash disbursement used is a Money Inventory (MI) accounting system in the form of Replace Money (RM), This study aims to evaluate the implementation of System and Inventory Money Prosedur at the planning, Reasearch and Development Agency of South Minahasa Regency throught descriptive analysis method collected by means of observation and interview. Based on the results of research implementation of system and money inventory procedures has been done effective way means it has been done effective way means it has been in accordance with the theory of accounting system and existing rules include related functions and documents used.
\end{abstract}

Keywords: Procedure, Money Inventory, Replace Money

\section{PENDAHULUAN}

Permasalahan keuangan daerah merupakan bagian yang tidak dapat dipisahkan dari pengelolaan keuangan daerah baik menurut Peraturan Menteri Dalam Negeri Nomor 55 Tahun 2008 tentang Tata Cara Penatausahaan dan Penyusunan Laporan Pertanggungjawaban Bendahara serta Penyampaiannya maupun Permendagri Nomor 13 Tahun 2006 tentang Pedoman Pengelolaan Keuangan Daerah kemudian disempurnakan dengan terbitnya Permendagri Nomor 59 Tahun 2007. Penatausahaan keuangan daerah mencakup asas umum penatausahaan keuangan, pelaksanaan penatausahaan keuangan daerah, penatausahaan penerimaan, penatausahaan pengeluaran serta penatausahaan pendanaan dan tugas pembantuan.

Lingkup penatausahaan pengeluaran diantaranya Penyediaan dana (SPD), Permintaan Pembayaran (SPP), baik SPP-UP (Uang Persediaan), masalah PP-GU (Ganti Uang), SPP-TU (Tambahan Uang) maupun SPP-LS (Langsung) baik SPP-LS Gaji dan Tunjangan dan SPPLS Barang dan Jasa serta Perintah Membayar (SPM) baik SPM-UP, SPM-GU, SPM-TU maupun SPM-LS Gaji dan Tunjangan maupun SPM-LS Barang dan Jasa, Pencairan dana (SP2D) serta pertanggungjawaban penggunaan dana. Uang persediaan merupakan istilah baru yang muncul dalam Permendagri No.13 Tahun 2006 tentang Pedoman Pengelolaan Keuangan Daerah. Menurut Pasal 1 angka 66 Permendagri No 13 Tahun 2006 dijelaskan bahwa SPP uang persediaan merupakan dokumen yang diajukan oleh bendahara pengeluaran untuk permintaan uang muka kerja yang bersifat pengisian kembali yang tidak dapat dilakukan dengan pembayaran langsung (Dian : 2017).

Dian 2017 juga menjelaskan mengenai uang muka kerja yang merupakan nama lain dari uang kas yang digunakan untuk melaksanakan kegiatan SKPD (Surat Keputusan Pemerintah Daerah) contohnya seperti pengadaan barang dan jasa dimana pembayarannya dilakukan oleh bendahara yang harus melalui pelelangan (tender), yang terlebih dahulu 
SKPD (Surat Keputusan Pemerintah Daerah) mengiklankan informasi tentang kegiatan tersebut di media massa. Pembayaran iklan ini dilakukan oleh bendahara pengeluaran dengan menggunakan Uang Persediaan (UP).

Badan Perencanaan, Penelitian dan Pengembangan (BAPELITBANG) Kabupaten Minahasa Selatan merupakan pemerintahan daerah dalam bidang perencanaan pembangunan daerah. Bapelitbang Minahasa Selatan sebagai badan perencanaan daerah mempunyai tugas pokok salah satunya adalah melakukan kegiatan belanja daerah. Tentunya kegiatan belanja daerah tersebut tidak terlepas dari uang persediaan. Pada dasarnya uang persediaan (UP) diberikan untuk pengeluaran belanja barang, belanja modal dan belanja lain-lain. Berdasarkan keterangan tentang uang persediaan yang telah dijelaskan di atas, penulis tertarik untuk melakukan evaluasi pada Badan Perencanaan, Penelitian, dan Pengembangan Daerah di Kabupaten Minahasa dengan judul "Sistem Dan Prosedur Uang Persediaan Pada Badan Perencanaan, Penelitian Dan Pengembangan Daerah Kabupaten Minahasa Selatan”

\section{TINJAUAN PUSTAKA \\ Pengertian Akuntansi}

Perubahan yang semakin cepat dalam masyarakat kita, telah menyebabkan semakin kompleksnya pengelolaan badan usaha atau perusahaan. Disamping itu adanya peningkatan aktivitas suatu perusahaan meningkatkan keperluan informasi mengenai suatu keadaan seluruh kegiatan perusahaan secara tepat dan dapat diandalkan. Informasi yang menyajikan keadaan tersebut dikenal sebagai akuntansi. Akuntansi merupakan bahasa bisnis dan dilaksanakan baik dalam perusahaan yang bertujuan mencari laba maupun perusahaanperusahaan yang tidak mencari laba. Pihak manajemen menggunakan akuntansi sebagai alat untuk membuat perencanaan serta pengendalian perusahaan.

\section{Akuntansi Sektor Publik}

Informasi akuntansi yang dihasilkan oleh suatu entitas sangat dipengaruhi oleh tipe organisasi itu sendiri. Tipe organisasi mempunyai lingkungan yang berbeda satu sama lain sehingga karakteristik informasi akuntansi yang dihasilkan juga akan berbeda. Pada sektor publik akuntansi sering kali diartikan sebagai akuntansi yang dihasilkan juga akan berbeda. Pada sektor publik akuntansi seringkali diartikan sebagai akuntansi dana masyarakat, yaitu teknis dan analisis akuntansi yang digunakan pada organisasi sektor publik.

\section{Tujuan Akuntansi Sektor Publik}

Akuntansi sektor publik berkaitan dengan tiga hal, yaitu penyediaan informasi, pengendalian manajemen dan akuntabilitas. Akuntansi sektor publik ini merupakan alat informasi bagi pemerintah maupun alat informasi bagi publik. Informasi akuntansi publik ini sangat bermanfaat untuk pengambilan keputusan, American Accounting Association menyatakan bahwa tujuan akuntansi pada sektor publik sebagai berikut (Mardiasmo:2002):

- Memberikan informasi yang diperlukan untuk mengelola secar tepat, efisiensi dan ekonomis atas suatu operasi dan alokasi sumber daya yang dipercayakan kepada organisasi. Tujuan ini terkait dengan pengendalian manajemen (management control).

- Memberikan informasi yang memungkinkan bagi manajer untuk melaporkan pelaksanaan tanggung jawab mengelola secara tepat dan efektif program dan penggunaan sumber daya yang menjadi wewenangnya, dan memungkinkan bagi pegawai pemerintah untuk melaporkan kepada publik atau hasil operasi pemerintah dan penggunaan dana publik. Tujuan ini terkait dengan akuntabilitas (accountability). 


\section{Ruang Limgkup Akuntansi Sektor Publik}

Salah satu kriteria keberhasilan dari akuntansi sektor publik adalah kondisi perekonomian. Keberhasilan organisasi sektor publik tidak terlepas dari pemahaman akan pentingnya akuntansi sektor publik dan pengaturan praktik-praktik akuntansi di organisasi sektor publik itu sendiri. Penataan yang baik terhadap akuntansi sktor publik harus dilakukan mengingat pentingnya peranan sektor publik dalam pemerintahan. Penetapan akan ruang lingkup akuntansi merupakan salah satu hal yang sangat substansial dalam penataan akuntansi sektor publik. Secara teoritis, akuntansi sektor publik merupakan bidang akuntansi yang mempunyai ruang lingkup lembaga-lembaga tinggi negara dan departemen-departemen dibawahnya, pemerintah daerah, yayasan, prtai politik, perguruan tinggi dan organisasiorganisasi non profit lainnya (Bastian:2006).

\section{Pengertian Sistem dan Prosedur}

Berbicara tentang sistem menimbulkan gambaran mental tentang komputer dan program, kenyataannya istilah ini memiliki makna yang lebih luas. Sebagian sistem muncul secara alami, sementara sebagian lain secara artificial. Sistem alam berkisar dari atom, suatu sistem yang terdiri atas elektron, proton dan netron. Sistem artificial merupakan buatan manusia, sistem ini meliputi segala sesuatu dari jam kehidupan bawah laut dari sistem sosial ke sistem informasi. Menurut Nugroho (2001:40) "sistem adalah sesuatu yang memiliki bagian-bagian yang saling berinteraksi untuk mencapai tujuan tertentu melalui tiga tahapan yaitu input, proses dan output".

\section{Anggaran Pendapatan Belanja Daerah}

Menurut Peraturan Menteri Dalam Negeri Nomor 13 Tahun 2006, struktur APBD merupakan satu kesatuan yang terdiri dari:

- Pendapatan Daerah, merupakan hak daerah yang diakui sebagai penambah nilai kekayaan bersih dalam periode tahun bersangkutan dan tidak perlu dibayar kembali oleh daerah. Pendapatan daerah meliputi semua penerimaan uang melalui Rekening Kas Umum Daerah yang menambah ekuitas dana.

- Belanja Daerah, meliputi semua pengeluaran uang dari Rekening Kas Umum Daerah yang mengurangi ekuitas dana, yang merupakan kewajiban daerah dalam satu tahun anggaran yang tidak akan diperoleh pembayarannya kembali oleh daerah.

- Pembiayaan Daerah, merupakan setiap penerimaan yang perlu dibayar kembali dan/atau pengeluaran yang akan diterima kembali, baik pada tahun anggaran yang bersangkutan maupun pada tahun-tahun anggaran berikutnya. Pembiayaan daerah adalah transaksi keuangan pemerintah daerah yang dimaksudkan untuk menutup defisit atau untuk memanfaatkan surplus APBD.

\section{Pengertian Uang Persediaan}

Menurut situs KPPN Serang (2015) menjelaskan bahwa Uang Persediaan merupakan uang muka kerja dari Kuasa BUN kepada Bendahara Pengeluaran yang dapat dimintakan penggantiannya (revolving). Mahmud, dkk (2016) mendefinisikan Uang Persediaan (UP) adalah sejumlah uang tunai yang disediakan untuk belanja operasional seharihari dari SKPD yaitu untuk belanja barang dan jasa, Uang Persediaan tidak bisa digunakan untuk belanja modal ataupun belanja honorarium.

\section{Penatausahaan Pengelola Keuangan Daerah}

Keuangan daerah dapat diartikan sebagai "semua hak dan kewajiban yang dapat ditandai dengan uang, demikian pula segala sesuatu baik berupa uang maupun barang yang 
dapat dijadikan kekayaan daerah sepanjang belum dimiliki/dikuasai oleh negara/daerah yang lebih tinggi serta pihak-pihak lain sesuai ketentuan/peraturan perundang-undangan yang berlaku”. (Halim 2004:18). Keuangan daerah dikelola melalui Manajemen Keuangan Daerah. Manajemen Keuangan Daerah adalah "pengorganisasian dan pengelolaan sumber-sumber daya atau kekayaan yang ada pada suatu daerah untuk mencapai tujuan yang dikehendaki tersebut". Alat untuk melaksanakan manajemen keuangan daerah disebut Penatausahaan Daerah.

\section{Sistem Informasi Pengeluaran Kas}

Sistem informasi akuntansi pengeluaran kas terbagi menjadi dua bagian yaitu sistem informasi akuntansi pengeluaran kas dengan cek dan sistem dana kas kecil. Sistem informasi akuntansi pengeluaran kas dengan cek adalah pengeluaran kas dengan menggunakan cek dan pengeluaran kas dengan menggunakan cek biasanya karena jumlahnya relatif besar.

\section{Penelitian Terdahulu}

- Penelitian yang dilakukan oleh Fery Prayitno (2016) berdasarkan hasil penelitiannya untuk mengevaluasi penerapan sistem dan prosedur uang persediaan (UP) di Dinas Pertanian dan Peternakan Provinsi Sulawesi Utara dilakukan sesuai dengan sistem akuntansi pengeluaran kas dan sesuai dengan aturan yang berlaku pada saat ini.

- Penelitian yang dilakukan Hady Kharitzah Raja (2016) hasil penelitiannya untuk mengetahui dan menganalisis apakah penerapan sistem dan prosedur uang persediaan dan ganti uang Dinas PU Kota Ternate sudah sesuai dengan peraturan yang berlaku.

\section{METODE PENELITIAN}

\section{Jenis Penelitian}

Jenis penelitian ini adalah deskriptif kualitatif, Penelitian kualitatif sebagaimana yang dikemukakan oleh Moleong (2012:6) Penelitian kualitatif adalah penelitian yang bermaksud untuk memahami fenomena tentang apa yang dialami oleh subjek penelitian misalnya perilaku, persepsi, motivasi, tindakan, dan lain-lain secara holistik, dan dengan cara deskripsi dalam bentuk kata-kata dan bahasa pada suatu konteks khusus yang alamiah dan dengan memanfaatkan berbagai metode yang alamiah.

\section{Jenis Data}

Menurut Sugiyono (2012: 189), bahwa data adalah keterangan mengenai sesuatu yang diperoleh dalam suatu penelitian untuk menjelaskan, menerangkan, dan memecahkan masalah-masalah sesuai dengan konteks judul yang diambil dengan maksud dan tujuan. Jenis data dapat dibedakan menjadi dua jenis, yaitu sebagai berikut.

- Data kualitatif merupakan data yang tidak dapat diukur dalam skala numerik atau data yang disajikan dalam bentuk deskriptif atau berbentuk uraian.

- Data kuantitatif merupakan data yang disajikan dalam bentuk skala numerik (angka).

Data yang digunakan dalam penelitian ini adalah data kualitatif yang tidak dapat diukur dalam skala numerik atau data yang disajikan dalam bentuk deskriptif atau berbentuk uraian.

\section{Sumber Data}

Menurut Sugiyono (2012: 193), bahwa sumber data merupakan data penelitian yang diperoleh peneliti secara langsung dari sumber asli, adalah sebagai berikut: 
- Data Primer yaitu data yang diambil langsung dari badan usaha (pihak internal perusahaan) berupa data dan informasi yang relevan dengan penelitian, lewat wawancara langsung dan pembagian kuisioner.

- Data Sekunder yaitu data yang dikumpulkan oleh lembaga pengumpul data dan yang telah dipublikasikan kepada masyarakat pengguna data.

Penelitian ini menggunakan Data Primer dan Data Sekunder. Adapun maksud dari kedua data tersebut yaitu:

- Data primer dalam penelitian ini adalah data hasil wawancara dan observasi dengan pihak terkait dalam pembuatan laporan keuangan,

- Data sekunder dalam penelitian ini adalah Dokumen berupa Tugas Pokok dan Fungsi Susunan Organisasi dan Daftar Nominatif Pegawai Negeri Sipil Badan Perencanaaan Penelitian Dan Pengembangan Kabupaten Minahasa Selatan.

\section{Metode Analisis}

Metode analisis data yang digunakan dalam penelitian ini adalah metode analisis kualitatif. Menurut Sugiyono (2012:89) menyatakan analisis data adalah proses mencari dan menyusun secara sistematis data yang diperoleh dari hasil wawancara, catatan lapangan,dan dokumentasi, dengan cara mengorganisasikan data ke dalam kategori, menjabarkan ke dalam unit-unit, melakukan sintesa, menyusun ke dalam pola, memilih mana yang penting dan yang akan dipelajari, dan membuat kesimpulan sehingga mudah dipahami.

\section{HASIL PENELITIAN DAN PEMBAHASAN Pembuatan Surat Penyedian Dana (SPD)}

SPD adalah Surat Penyediaan Dana, yang dibuat oleh BUD dalam rangka manajemen kas daerah. Manajemen kas adalah kemampuan daerah dalam mengatur jumlah penyediaan dana kas bagi setiap SKPD, artinya BUD harus mampu memperkirakan kemampuan keuangan Pemda dalam memenuhi kebutuhan dana SKPD. Hal ini penting, karena akan mengurangi jumlah dana yang dapat disediakan dalam satu kali pengajuan SPD, serta periode pengajuan SPD.

\section{Pengajuan Surat Permintaan Pembayaran (SPP)}

Berdasarkan SPD atau dokumen lain yang dipersamakan dengan SPD, bendahara pengeluaran mengajukan Surat Pengantar SPP (Surat Permintaan Pembayaran) kepada pengguna anggaran /kuasa pengguna anggaran melalui Pejabat Penatausahaan Keuangan SKPD

\section{Penerbitan Surat Perintah Membayar (SPM)}

Proses Penerbitan SPM adalah tahapan penting dalam penatausahaan pengeluaran yang merupakan tahap lanjutan dan proses pengajuan SPP. Sebagai tahap lanjutan, SPM juga dibedakan menjadi empat sesuai dengan jenis SPPnya, yaitu SPM UP, GU, TU, dan LS. Proses ini dimulai dengan pengujian atas SPM yang diajukan baik dari segi kelengkapan dokumen maupun kebenaran pengisiannya. Untuk SPM GU, pengujian juga dilakukan atas SPJ yang diajukan oleh bendahara. Begitu juga untuk SPM TU jika sebelumnya telah pernah dilakukan.

\section{Penerbitan Surat Perintah Pencairan Dana (SP2D)}

SP2D atau Surat Perintah Pencairan Dana adalah surat yang dipergunakan untuk mencairkan dana lewat bank ditunjuk setelah SPM diterima oleh BUD. SP2D adalah spesifik, artinya satu SP2D hanya dibuat untuk satu SPM saja. 


\section{Pelaksanaan Belanja Penggunaan Uang Persediaan}

Pelaksanaan belanja yang dilakukan untuk melakukan suatu kegiatan wajib di pertanggungjawabkan pelaksanaan belanja tersebut. PPTK secara tepat waktu. Dalam mempertanggungjawabkan pelaksanaan belanja tersebut PPTK harus melampirkan dokumendokumen pendukung penggunaan anggaran dalam pelaksanaan kegiatan yang terkait. Dokumen penggunaan anggaran diberikan kepada Bendahara Pengeluaran sebagai dasar bagi Bendahara Pengeluaran untuk membuat surat pertanggungjawaban (SPJ).

\section{Pembuatan Surat Pertanggungjawaban (SPJ) Pengeluaran}

Bendahara pengeluaran secara administratif wajib mempertanggung jawabkan penggunaan uang persediaan/ganti uang persediaan/tambahan uang persediaan kepada Kepala SKPD melalui PPK-SKPD paling lambat tanggal 10 bulan berikutnya.

\section{Pembuatan Surat Pertanggungjawaban (SPJ) Pengeluaran Pembantu}

Bendahara pengeluaran pembantu wajib menyelenggarakan penatausahaan terhadap seluruh pengeluaran yang menjadi tanggung jawabnya. Bendahara pengeluaran pembantu wajib menyampaikan laporan pertanggungjawaban pengeluaran kepada bendahara pengeluaran paling lambat tanggal 5 bulan berikutnya.

\section{Pembuatan Surat Pertanggungjawaban (SPJ) Pengeluaran Pembantu}

Bendahara pengeluaran pembantu wajib menyelenggarakan penatausahaan terhadap seluruh pengeluaran yang menjadi tanggung jawabnya. Bendahara pengeluaran pembantu wajib menyampaikan laporan pertanggungjawaban pengeluaran kepada bendahara pengeluaran paling lambat tanggal 5 bulan berikutnya.

\section{Pembahasan}

Evaluasi Sistem dan Prosedur Uang Persediaan Pada Badan Perencanaan Penelitian dan Pengembangan yang ada telah membentuk sistem dan sesuai dengan Flow chart yang baku, namun penerapannya sering terjadi keterlambatan pada masing-masing unit kerja. Setiap unit kerja memiliki SOP (Standar Operation Prosedur) sehingga apabila terdapat keterlambatan maka itu disebabkan oleh karena adanya staf yang menunda-nunda pekerjaan ataupun karena adanya masalah jaringan. Hal itulah yang mengakibatkan prosedur atas uang persediaa pada Badan Perencanaan Penelitian dan Pengembangan berjalan lambat. Untuk itu sebaiknya setiap pihak terkait menjalankan tugas sesuai dengan tanggung jawabnya agar tidak terjadi keterlambatan dan kesalah pahaman dalam pekerjaan.

\section{KESIMPULAN DAN SARAN}

\section{Kesimpulan}

Pelaksanaan Sistem dan Prosedur Uang Persediaan Pada Badan Perencanaan Penelitian dan Pengembangan telah dilakukan sesuai dengan aturan yang berlaku, Bendahara penerimaan maupun pengeluaran telah melakukan penatausahaan dan penyusunan laporan pertanggungjawaban serta pencatatan atas uang persediaan mengacu pada Peraturan Pemerintah Dalam Negeri NO. 13 Tahun 2006. Serta aturan yang ada mencakup fungsi yang terkait, dokumen yang digunakan, catatan akuntansi yang digunakan dan jaringan prosedur sistem akuntansi pengeluaran kas.

\section{Saran}

- Dalam pelaksanaan sistem dan prosedur uang persediaan membutuhkan perangkat pendukung teknis yang mampu bekerja dan digunakan optimal sehingga penyusunan 
laporan dapat dilakukan dengan baik. Perangkat pendukung teknis merupakan unit komputer yang mampu melaksanakan perhitungan-perhitungan dengan cepat dan akurat.

- Diharapkan adanya pelatihan dalam bidang akuntansi agar dalam proses kinerja dapat berjalan sesuai yang diharapkan, sehingga mengurangi keterlambatan dan kesalah pahaman dalam pekerjaan, agar Sistem Dan Prosedur Uang Persediaan Pada Badan Perencanaan Dan Penelitian dapat dijalankan dengan baik.

\section{DAFTAR PUSTAKA}

Accounting Principles Board (APB), Statement No.4, Basic Concepts and Accounting Principles Underlying Financial Statement of Business Enterprise. Part 40.1971.

American Accounting Assoction (AAA), Financial Accounting Standards Committee (FASC). (2005), Response to the FASB's exposure draft: FVAs. Accounting Horizons, 19. 187-196.

Ariel S. Sumenge. 2013, Analisis Efektifitas Dan Efisiensi Pelaksanaan Anggaran Belanja Badan Perencanaan Pembangunan Daerah (BAPPEDA) Minahasa Selatan. Jurnal Emba. Vol.1 No.3.

Aroran. Venna Maria. Jantje dan Novi. 2016, Evaluasi Penerapan Sistem Pengendalian Penerimaan Kas (Studi Kasus Pada Dinas Pendapatan Daerah Kota Manado). Jurnal Berkala Ilmiah Efisiensi Volume 16 No. 03 Tahun 2016.

Badan Akuntansi Keuangan Negara (BAKUN) Departemen Keuangan RI Jakarta. DPR RI, 2003.

Departemen Keuangan Republik Indonesia. Undang - undang Nomor 33 Tahun 2004 tentang Perimbangan Keuangan Antara Pemerintah Daerah dan Pemerintah Pusat. Lembaran Negara Republik Indonesia. Tahun 2004 No. 126. Sekretariat Negara Jakarta.

Feri Prayitno. 2016, “Evaluasi Penerapan Sistem Akuntansi Uang Persediaan Pada Dinas Pertanian Dan Peternakan Provinsi Sulawesi Utara. Jurnal EMBA Vol.4 No.2.

Hady Kharitzah Raja. 2016, Analisis Penerapan Sistem Prosedur Uang Persediaan Dan Ganti Uang Pada Dinas Pekerjaan Umum Kota Ternate Maluku Utara. Jurnal EMBA: Vol.4 No.3.

Iren Tessa. Kapoh, Herman dan Harijanto. 2015. Evaluasi Pelaksanaan Sistem Dan Prosedur Pengeluaran Kas Uang Persediaan Pada Dinas Pariwisata Dan Kebudayaan Kota Manado. Jurnal EMBA Vol.3 No.1.

Janis. Raisa Stephanie., Jullie dan Harijanto. 2015. Analisis Sistem Dan Prosedur Penerimaan Pad Pada Dinas Pendapatan Pengelolaan Keuangan Dan Aset Daerah Kabupaten Sitaro. Jurnal EMBA. Vol.3 No.1.

Lahay. Novita. 2013. Analisa Pelaksanaan Sistem dan Prosedur Pengeluaran Kas Pada Dinas Pekerjaan Umum (PU) Provinsi Sulawesi Utara.Vol.1. No.3.

Languju. Virgia. 2015. Evaluasi Pelaksanaan Sistem dan Prosedur Pengeluaran Kas Pada Dinas Perindustrian dan perdagangan Provinsi Sulawesi Utara. Vol.3. No.1.

Mahmud. Rahmad, Jullie dan Novi. 2016. Analisis Sistem Dan Prosedur Pengeluaran Kas Dengan Menggunakan Uang Persediaan (Up) Pada Dinas Sosial Kota Manado. Jurnal EMBA, Vol. 4 No .2.

Mulyadi. 2013, Sistem Akuntansi edisi 3 : Salemba Empat : Jakarta.

Peraturan Dalam Negeri No.13 Tahun 2006, Tentang Pedoman Pengelolaan Keuangan Daerah. Jakarta, 2006.

Raja, Hady Khatrizah. 2016. Analisis Penerapan Sistem Prosedur Uang Persediaan Dan Ganti Uang Pada Dinas Pekerjaan Umum Kota Ternate Maluku Utara. Jurnal EMBA Vol. 4 No. 3 September 2016. 